\title{
TREE RINGS AND THE CHRONOLOGY OF ANCIENT EGYPT
}

\author{
PEARCE PAUL CREASMAN
}

Laboratory of Tree-Ring Research, University of Arizona, 1215 E. Lowell St., Tucson, AZ 85721, USA. Corresponding author: pcreasman@1trr.arizona.edu.

\begin{abstract}
A fundamental aspect of ancient Egyptian history remains unresolved: chronology. Egyptologists (and researchers in related fields that synchronize their studies with Egypt) currently rely on a variety of insufficiently precise methodologies (king lists, radiocarbon dating, etc.) from which to derive seemingly "absolute" dates. The need for genuine precision has been recognized for a century, as has the potential solution: dendrochronology. This manuscript presents a case for further progress toward the construction of a tree-ring chronology for ancient Egypt.
\end{abstract}

Keywords: Egyptology, chronology, dendrochronology, tree rings, Near East, Mediterranean.

\section{INTRODUCTION}

Archaeologists, historians, linguists, and other scholars in Egyptology regularly publish as fact data known to be inaccurate or problematic: calendrical dates. Although calendar dates (along with a variety relative dating methods) frame all works and publications regarding ancient Egypt, precise dates for the ancient world seem to be regarded as a tangential category of scientific data, one to which the high standards of scholarly inquiry are not consistently applied. The innate scholarly desire to organize the past instead absolves chronological transgressions through the use of circas. This creates sweeping problems for the understanding of history not only in Egypt but the entire ancient Mediterranean and Near East, timelines that necessarily rest on the interpretation of the Egyptian historical and archaeological record (e.g. Bruins 2010).

Currently, precise calendrical dating for ancient Egypt extends only to the transition from the Twenty-fifth Dynasty to the Twenty-sixth in 664 BC (see Schneider 2010). While strong arguments for the certainty of earlier dates have been offered (e.g. Khan [2006] for 721 BC; Kitchen [2013] for 690 BC), general agreement in the field appears to extend only to the noted dynastic transition (Creasman 2013a). Published dates for events prior to $664 \mathrm{BC}$ therefore range in reliability from useful approximations (at best) to dubious over-reaches. Even this date of $664 \mathrm{BC}$, more than 5 centuries after the fall of Egypt's exalted New Kingdom, was ascertained only through arduous efforts by a dedicated subset of scholars within the field. It leaves unresolved the entire period most often conceived of as "ancient Egypt" (the Predynastic; Old, Middle, and New Kingdoms; and three intermediate periods). Consequently, more than 3 millennia of complex human activity remain subject to copious debate and approximation, aligned through a variety of insufficiently precise sources and methodologies, including astronomical orientations, Sothic cycles, other ancient king lists, synchronisms with other cultures, and radiocarbon dating (e.g. Spence 2000; Hornung et al. 2006; Bronk Ramsey et al. 2010; Dee et al. 2010; Schneider 2012; Shortland and Bronk Ramsey 2013). Many Egyptologists balance the desire for chronological accuracy with the problems of dating by drawing either from relative methodologies (citing, e.g. reigns and dynasties) or from one published conventional chronology or another (e.g. Shaw 2000b; Redford 2001), often overlooking the implications of the differences among them simply because precision (that is, exact calendar dates for past events and processes) seems unobtainable. It is, perhaps, absolute dating fatigue - brought on by an endless cycle of calendar dates for certain events being presented as sound, opposed by one camp or another, and revised again or discarded - that has contributed to a reliance on general works that, regardless of their chronological variances and approximations, are of agreed high quality (Shaw 2000b; Redford 2001).

King lists and texts referring to specific regnal years form the linchpin of current Egyptological dating. The ancient Egyptians did not number the years of their calendars from a fixed point in time; rather, a new counting of years began typically with the ascension of a new king (Tausret's reign at the end of the Nineteenth Dynasty provides an example of an exception to this generality [see Wilkinson 2012; Creasman et al. 2014]). All dates assigned in antiquity to any event, great or small, are given in this manner. Thus, we know, for example, that Ramesses II fought against the Hittites in the battle of Kadesh in the fifth year of his reign (Lichtheim 1976:60), and that, 47 years later, a man named Tjay transported a cow (Janssen 1961:43). 
This would seem to present the possibility of developing a relatively straightforward chronology (especially since other ancient societies lacking written records and with much less material culture from which to work have been temporally resolved, notably in the American Southwest [Douglass 1929; Nash 1999]), were it not for an incomplete and sometimes contradictory historical record, problems presented by coregencies, and other irregularities in the data. Prime examples of these difficulties can be found in the late Eighteenth Dynasty, which includes a hypothesized coregency between Amenhotep III and Amenhotep IV/Akhenaten, the length (and existence) of which is much debated (e.g. Giles 2001; Dorman 2009). The dynasty comes to a close with the reign of Horemheb, to whom various scholars ascribe a reign as short as 13 years or as long as 35 (van Dijk 2008:200). Simultaneously, aligning textual and archaeological evidence from neighboring regions with even seemingly "stable" (albeit floating) segments of Egyptian historically resolved chronology can pose difficult problems (e.g. van Dijk 2008). Likewise, synchronizing ancient relative chronologies with episodes of natural disasters that left telltale evidence across the region, such as the volcanic eruption that devastated the island of Santorini sometime in the Bronze Age, remains contentious (Höflmayer 2012; Manning and Kromer 2012).

Of all the geochronologic and archaeometric methods of dating, only dendrochronology can provide precise, single-year dates (often with seasonal resolution) for past events and processes. This level of precision is essential for resolving ancient Egypt's chronology, given that some 150 of the approximately 300 known pharaohs ruled for less than a decade each (many for less than 5 years), periods far too brief for the resolution offered by other scientific dating methods (e.g. ${ }^{14} \mathrm{C}$ ). Despite its great promise, there is at present no tree-ring chronology for the pharaohs.

Andrew E. Douglass, the founder of dendrochronology, explored the possibility of applying the methods of tree-ring dating to ancient Egyptian artifacts at least as early as 1924 (Allen 1924), 4 years before prehistoric structures were dated by tree rings anywhere in the world (see Nash 1999:23), including the region where dendrochronology was founded: the American Southwest. A dry region akin to the Southwest, the Near East, specifically including Egypt, possesses all of the ingredients for archaeological tree-ring dating (Bannister and Robinson 1975:213). As will be shown, the few attempts to apply dendrochronological methods during the past 90 years have left the matter of ancient Egyptian dates unresolved but in position to advance.

Recent years have witnessed a rise in studies of ancient Egyptian environment and climate (e.g. Ghilardi and Boraik 2011; Bernhardt et al. 2012; Butzer 2012), human/environment interactions (e.g. Graham et al. 2012; Creasman 2013b), and absolute dating (largely through ${ }^{14} \mathrm{C}$; e.g. Bronk Ramsey et al. 2010; Dee et al. 2010; Quiles et al. 2013). As dendrochronology has made significant contributions to these same kinds of inquiries elsewhere in the world, this paper argues for the necessity of further progress toward the construction of a tree-ring chronology for the pharaonic and earlier periods. Eventually, "the entire prehistoric and early historic chronology of Egypt and the Near East will have to be revised, using the more secure chronological framework that dendrochronology can offer" (Renfrew 1996:733). With a concerted and collaborative effort, this eventuality may become reality.

For nearly a century, tree rings have offered insights into chronology and into past natural and human events (e.g. Douglass 1929), including dates of prehistoric structures and migrations, millennia-long histories of drought and temperature, corroboration and calibration of ${ }^{14} \mathrm{C}$ dating, and long-term river flows with implications for modern water management (e.g. Suess 1970; Woodhouse and Overpeck 1998; Gray et al. 2011). Tree rings offer essential data for revealing and understanding complex interactions between natural and human systems, with valuable lessons for the present and future. Chronological, behavioral, and environmental studies such as these continue today and have expanded to include virtually all periods of history and cultures, notably excluding ancient Egypt.

\section{A BRIEF HISTORY OF DENDROCHRONOLOGY AND ANCIENT EGYPT}

In the 1920 s, A. E. Douglass was in contact with prominent Egyptologists to explore the possibility of constructing a treering-based chronology for ancient Egypt. By the early 1930s, they concluded that the museums of the world already held a sufficient volume of wooden archaeological remains to facilitate substantial progress in the endeavor (Breasted 1933). On several occasions, Douglass and those working directly under his supervision attempted to pursue the case for dendrochronology of ancient Egypt, but external circumstances ultimately prevented further progress.

Efforts began well. Notably, Emil Haury collected specimens from the Boston Museum of Fine Arts in the early 1930s, concluding: "I believe it is not unlikely that tree-rings might well substantiate and possibly amplify" the chronology of ancient Egypt (Haury 1935:108). With this confidence and contemporary successes in dating archaeological ruins in the American Southwest, Douglass attempted to hire a technician dedicated to development of an Egyptian dendrochronology (Douglass 1936). Unfortunately, within a matter of weeks the technician had accepted a position elsewhere (Nash 1999:203) to pursue work, like so many others, in the Southwest. It seems that Douglass' direct efforts tapered out soon after, ending with the onset of World War II (Creasman et al. 2012). Since him, numerous other scholars have called for the construction of a tree-ring chronology for Egypt or the proxy records it provides, including James H. Breasted (1933), Emil Haury (1935), Ambrose Lansing (1938), Ludlow Bull (1942), Bryant Bannister (1970, 1985), Jeffrey S. Dean (1978), Colin Renfrew (1996), Peter Ian Kuniholm (1992, 2002), Ian Shaw (2000a), Otto Cichocki (2000, 2006), Nadine Moeller (2005), Kenneth A. Kitchen (2006), Malcolm H. Wiener (2006), and others. 
Despite this recognition of need and possibility, few efforts have extended to Egypt itself. Bryant Bannister, the first to visit Egypt and collect tree-ring specimens there, confirmed the viability of cedars imported in antiquity for the most essential concept in dendrochronology: crossdating (Bannister 1970, 1985). Having analyzed the specimens that Bannister collected, Jeffrey S. Dean concluded: "a study of wood samples from an Egyptian pyramid indicates that future successes in this area are possible" (1978:140). Bannister and Dean, both specialists in the U.S. Southwest, did not directly advance the case for Egypt further. Instead, they encouraged Peter Ian Kuniholm, whose primary focus on Aegean dendrochronology never led to the collection of materials in Egypt but did include the assembly of a significant, if small, set of wood samples from Egyptian artifacts in Western museums. Kuniholm (2001a, 2001b) crossdated two floating cedar chronologies that originated from different sites in Egypt and periods of history: a Twelfth Dynasty boat (Carnegie Museum of Natural History 1842-1) from the site of Dahshur and an older coffin (Oriental Institute Museum 12072), likely of Eleventh Dynasty date, from Saqqara, some $10 \mathrm{~km}$ away. This considerably advanced the case for the application of dendrochronology to anciently imported materials, but as Egypt was largely outside the scope of Kuniholm's work, it was not advanced further. The specimens have, however, recently been used in new chronological evaluations in hopes of narrowing the margin of error for ${ }^{14} \mathrm{C}$ dating (Manning et al. 2014).

Aside from the occasional collection and analysis of Egyptian specimens from museums and institutions outside of Egypt (e.g. Kromer 1991), little additional progress was made until the launch of Synchronisation of Civilisations in the Eastern Mediterranean in the Second Millennium BC (SCIEM 2000). A multifaceted program supported by the Austrian Academy of Sciences, SCIEM 2000 specifically included Egypt within its dendrochronology component (Cichocki 2000, 2003). This resulted in the sampling of at least 161 archaeological objects in museums and a (presumably smaller) number collected from two archaeological sites in Egypt (http://www.oeaw.ac.at/sciem2000/Pr07main.html, accessed 28 January 2014). The project, which has oriented all of its collection activity toward imported cedars (Cichocki 2006; no other species are reported to have been collected) and produced only floating chronologies, has resulted in two significant events. Of foremost importance, the team acquired ring-width measurements from 15 objects in the Egyptian Museum, Cairo: the first successful such effort in a museum in Egypt. The current author's empirical observations have led to the conclusion that museums and archaeological storehouses in Egypt hold multiple tons of wood from contexts securely dated to specific reigns and years within these reigns. Work with such resources will be critical to the construction of a fixed chronology via tree rings. Secondly, working with small group of archaeologists in Egypt, the SCIEM project visited active excavations to collect specimens. Continuing and expanding both achievements will be critical to long-term successes.
Unfortunately, despite the labors and foundational works noted, there has been no effort to collect or analyze tree-ring materials in or from Egypt with the organization or frequency necessary to contribute to larger chronological, behavioral, or environmental analyses for any period of its history. Resolving such a long and complicated history will require the study of tens of thousands of specimens or perhaps even more.

\section{IS DENDROCHRONOLOGY POSSIBLE FOR AND IN EGYPT?}

As a result of favorable preservation conditions and the ancient Egyptian practice of ritually provisioning individuals for the afterlife, archaeological excavations in Egypt have recovered an abundant if unquantified large volume (e.g. multiple tons) of human-modified wood. This includes both native and imported species (e.g. of the latter, approximately 38 tons of imported Cedrus libani compose one Old Kingdom ship excavated in the 1950s [Mark 2009:133]). Ancient ships, coffins and other funerary equipment, furniture, statuary, and architectural timbers provide a potential source of material for tree-ring research (Figure 1). Such items fill museums and storehouses throughout Egypt and elsewhere and in many cases receive little academic attention.

As evidenced by the aforementioned works, construction of a tree-ring-based chronology for cedars and other imported timbers derived from Egyptian archaeological contexts is indeed possible. The basic principles of tree-ring research (Bannister 1963) have been successfully demonstrated for $C$. libani, the most common timber import, within the circumstances encountered in Egypt. Tree-ring research in the region widely uses other imports, including Cupressus sp., Juniperus sp., and Pinus sp. (see Bardinet [2008] for thorough discussions of each), so these genera should prove similarly useful in Egypt (e.g. Liphschitz 2007; Touchan and Hughes 2009; Touchan et al. 2011; Griggs et al. 2013).

However, imported timbers in Egypt come with complicating factors (see Cichocki [2000:64-65] and Cichocki et al. [2004:97], in addition to subsequent citations). The Egyptians valued wood, particularly the imported coniferous woods, sufficiently to prompt its frequent reuse (Creasman 2010a, 2010b, 2013b). Such timber repurposing as the Egyptians practiced will provide dendrochronological efforts with both advantages and challenges. During the chronology-building process, a mixture of first-use and reused wood can yield a greater number of annual rings with which to work than might a collection of only first-use timber, permitting the construction of longer site chronologies and floating chronologies. However, the same practice will likely complicate dating efforts for individual artifacts or sites. Even when dates are available (that is, when the outermost rings remain and can be fit into a master chronology), they will skew older if the construction episode under consideration utilized little or no new material. Similarly problematic is that we do not know how much time typically passed between the felling of timber in a foreign land (and seasoning, if any), its transport to Egypt, and its eventual use there. 


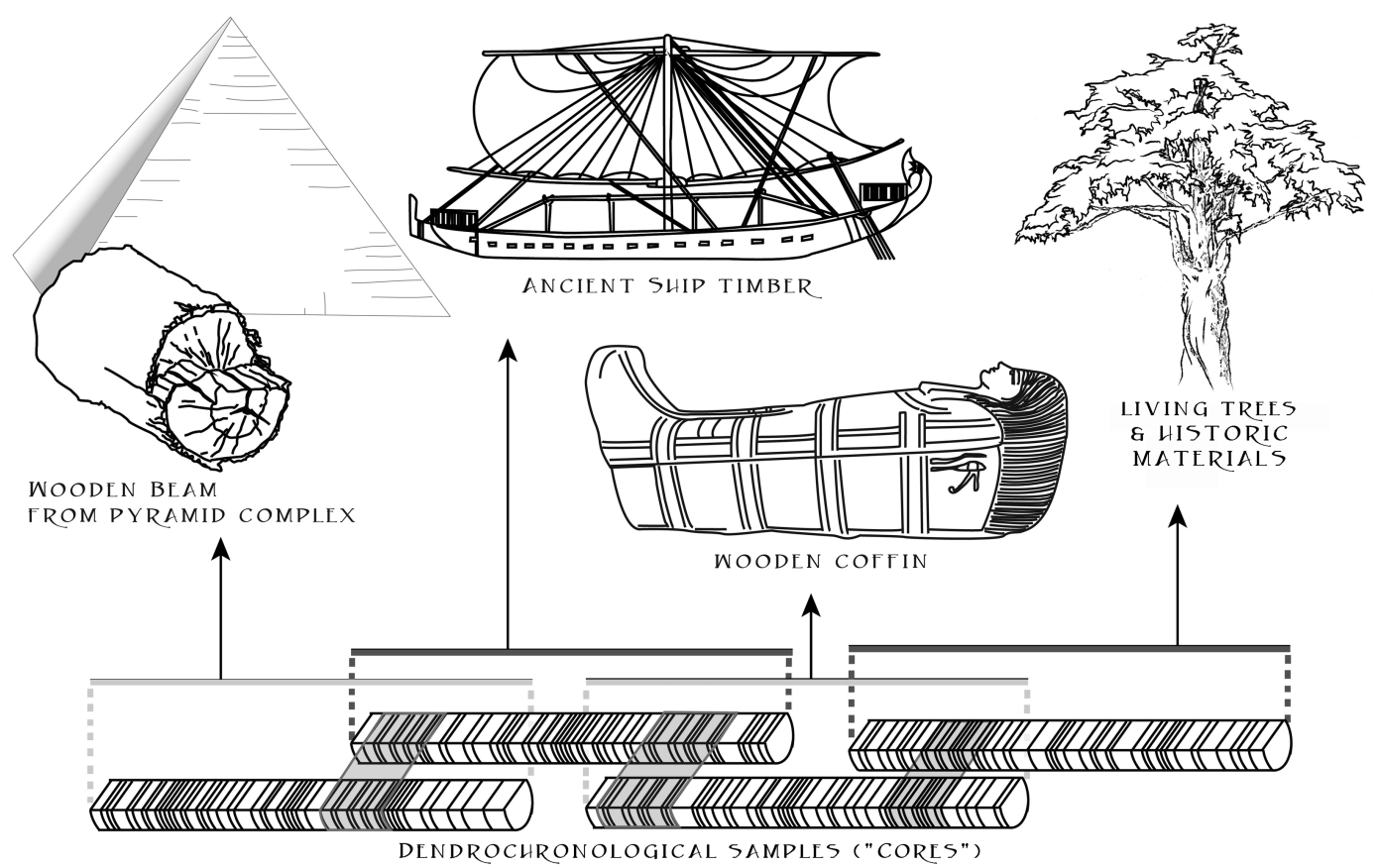

Figure 1. Conceptual chronology building via tree rings for ancient Egypt; not to scale (R. Caroli/P. P. Creasman; @ University of Arizona Egyptian Expedition).

Furthermore, the practice of stockpiling timber, including "old" wood, in Egypt is known from at least as early as the Middle Kingdom (Simpson 1965; Dee et al. 2012; Creasman 2013b).

Although proposed and briefly pursued much earlier (Robinson 1967), the field of tree-ring analysis has focused only recently on archaeological wood-use behaviors. The essential concept behind such studies is "[t]he more we understand the behavior involved in wood procurement, use, discard and consumption, the better we will be able to assign unambiguous dates to human events" (Dean 1996:466). This is especially important for societies, such as pharaonic Egypt, that made intensive use of wood and lack reliable chronologies. Before relying on imported timbers to provide dates for past events in ancient Egypt, we need to develop a much greater understanding of wood-use behaviors, notably reuse and other aspects of the timber economy (Dixon 1974; Deglin 2012; Creasman 2013b, 2014).

Thus far, Egyptological tree-ring studies have subjected only imported species to rigorous evaluation of their potential. Even the most fundamental question remains unanswered for native Egyptian species: can dendrochronology be applied to them with success? Using dendrochronology to its fullest potential-for example, to evaluate and reconstruct environmental events and their impacts (i.e. theories of dynastic collapse; Bell 1971, 1975; Moeller 2005; Hassan 2007; Butzer 2012)—will require analysis of specimens that grew in Egypt and thus reflect the local conditions, rather than those of distant lands (e.g. cedars of Lebanon). If tree-ring studies for Egypt can incorporate native species, they could yield critical perspectives on the environment, including Nile flood levels, periods of drought or pestilence (both of which trees can evince), and other issues that have modern relevance, including resource management and climate change. Determining the viability of native Egyptian woods commonly used in ancient times for tree-ring analyses has yet to be accomplished.

Excluding palms, which do not produce tree rings, the three most commonly used native Egyptian woods in ancient times are (per Cichocki et al. 2004) acacia (Acacia nilotica), fig (Ficus sycomorus), and tamarisk (Tamarix sp.). The utility for tree-ring research for these species in Egypt has yet to receive adequate examination (Creasman, in press). Ficus sycomorus and Acacia nilotica failed to work for Bannister in the 1970s, and others since then have found them to be similarly problematic (B. Bannister, personal communication, 10 October 2011), leading researchers to dismiss them as unusable. However, none of the Egyptian varieties has undergone a thorough evaluation. While the biological growth characteristics of $F$. sycomorus do, indeed, make it an unlikely candidate for dendrochronology (i.e. it appears not to form annual rings), it should still be evaluated as a potential source, given that on many occasions studies have revealed that genera/species once thought not useful for dendrochronology can in fact yield a wealth of information (e.g. African frankincense trees [Tolera et al. 2013] and certain tropical species [Trouet et al. 2012]; N.B. until about 1970 apparently all trees in England and Ireland were believed to fall into this category [Baillie 1982:22]). Moreover, investigations have demonstrated the dendrochronological viability of Acacia sp. and Tamarix sp. in other arid/semiarid regions, including the Near East and Ethiopia (e.g. Gourlay 1995a, 1995b; Eshete and Ståhl 1999; Touchan and Hughes 2009; Nicolini et al. 2010; Wils et al. 2010, 2011). Egyptians employed these genera extensively - for example, in the construction of a 
fence forming the enclosure around a Predynastic tomb at Hierakonpolis (Adams 2001), dynastic period boats (Ward 2000), and many other structures and objects from the Neolithic to Roman period (Gale et al. 2000), and nomadic pastoralists have made use of some to the present (Andersen et al. 2014). This makes analyses (specifically including anatomical evaluation [as in Fahn et al. 1986; Andersen and Krzywinski 2007; Akkemik and Yaman 2012]) of Egyptian examples of these woods essential.

Aside from the scientific evaluation of potential specimens, this endeavor must consider other practical matters. The most limiting factor in the pursuit of a tree-ring chronology for Egypt is access to specimens. When sufficient quantity and quality of specimens have been secured in dendrochronology, success has generally followed. Many, although not all, museums worldwide prohibit sampling of artifacts for scientific analyses. Collection of enough specimens to make reasonable progress will require a multifaceted agreement with the archaeological and museum authorities in Egypt, where the majority of the potential specimens are located. Although such an agreement will likely preclude sampling diagnostic objects (e.g. sculptures), thousands of other candidates sit in archives and storage magazines throughout Egypt from which progress can be made. Similarly, Western museums contain thousands of potential specimens. For objects of art and other intrinsically valuable wooden items, less invasive methods (such as those used to date European artworks; Kuniholm 2000) or noninvasive methods (e.g. X-ray computed tomography scanning; Grabner et al. 2009) are possibilities but present their own challenges, such as access to the necessary equipment and in the latter case, refinements in methodology are still needed. Cichocki et al. (2004) used modified flatbed scanners to capture images of exposed wood grains on coffins and worked from the electronic files. However, because most potential specimens do not have a fine enough surface and will at least require sanding, this method is unlikely to be widely applicable. The collection, over time, of a sufficient number of specimens will require a suitable archive and research space in Egypt. Ideally, active excavations and museum projects would, as a matter of general practice, submit any and all possible specimens to a centralized repository/laboratory where they could be evaluated.

Since 1983, Egypt's Antiquities Authority (a predecessor of today's Ministry of Antiquities) has had in place a prohibition against the removal from the country of archaeological materials, which now includes scientific specimens. Even if concern regarding sampling wooden objects can be overcome (as others have elsewhere in the world), under the present circumstances any tree-ring specimens collected from the country's vast reserves of wooden artifacts are likely to be restricted to analysis and archiving within the country. This is not prohibitive for the conduct of research itself because much tree-ring analysis requires relatively little equipment (all of which can be legally imported). However, the longterm nature of dendrochronological work and the usual tendency of dendrochronologists to evaluate specimens in their home laboratories do make such constraints a critical consideration.
Fortunately, a model already exists in Egypt for the scientific evaluation of archaeological materials: the Laboratoire de datation par le radiocarbone of the Institut français d'archéologie orientale. Opened in Cairo in 2006, it is the only such archaeological laboratory in Egypt and processes all ${ }^{14} \mathrm{C}$ specimens within the country. If cooperation of the necessary authorities can be similarly secured for dendrochronology, there is great hope for its application to wooden remains now in Egypt. To this end, the author has proposed and sought funding for the creation of a program that would, with the cooperation of Egyptian universities and museums, train Egyptian students and archaeologists in dendrochronology at the Laboratory of Tree-Ring Research in Tucson, Arizona, and return them to work at facilities in their home country. In any event, it will be essential to engage Egyptians in the process.

Current regulations necessitate the establishment of not only a dendrochronological research facility but also a tree-ring repository and archive in Egypt, preferably sharing a location with the laboratory. The analogy of dendrochronology as assembly of a jigsaw puzzle explains this need aptly (e.g. Baillie 1982). Researchers collect puzzle pieces from a wide variety of sources (in this case, tree-ring specimens from archaeological sites and museum collections) and subsequently assemble them, a task requiring years. Long-term preservation and continued access to specimens are crucial to this field because the significance of an individual specimen may become evident only years or even decades after its collection, when sufficient other specimens have been obtained for comparison to it, thus allowing potential completion of the "puzzle." Specimens must remain available for new observations, as vouchers for past research, and for the employment of different types of analyses and technologies (Creasman 2011). Furthermore, the ongoing loss of tree-ring resources due to environmental and social changes (e.g. looting and site destruction) will render extant wooden material increasingly valuable for study by biologists, earth scientists, and archaeologists in the coming decades and centuries.

\section{CONCLUSIONS}

Presently, Egyptology (along with all related fields that draw from Egyptian chronology) has only the option to fit chronology into the combined historical and archaeological record, a source of considerable debate and confusion. Dendrochronology can stand alone and independent, as an arbiter of time into which the historical record can be placed.

Despite the outstanding issues and concerns noted, efforts to construct a tree-ring chronology for ancient Egypt have, perhaps, the most favorable conditions of any such ambitious endeavor yet to be undertaken in dendrochronology. Ample material for meaningful progress exists and is accessible in museums and storerooms, including species known to be scientifically viable and others with yet unknown utility. The task will also greatly benefit from the examples of similarly complex projects that 
have come before, including the recent establishment of scientific laboratories in Egypt, the laying down of a retrospective "road map" regarding the construction of archaeological chronologies (Robinson 1976), and the development of multiple millennia-long chronologies (Ferguson 1969).

The proliferation of competing chronologies among Egyptological publications, unresolved lengths of reigns, the discovery of new kings (e.g. Woseribre Senebkay of the so-called Abydos Dynasty, discovered in January 2014 [Kingsley 2014]; cf. Ryholt 1997), and numerous other issues underscore the need to supplement traditional Egyptological approaches with dendrochronology and its precision.

Others have noted that " $[\mathrm{t}]$ he existence of a reliable chronological framework on which to chart the development of prehistoric cultures not only profoundly changed the structure of southwestern investigations but also altered the thinking of all New World archaeologists" (Bannister and Robinson 1986:51). Such a framework for ancient Egypt would equally transform our imperfect understanding of the Old World. Its benefits would include not only calendar dates for past human events and natural processes, but also preparation of regional ${ }^{14} \mathrm{C}$ calibration, flood reconstructions, and large-scale climate analyses.

Vital to all — indeed, any - such significant contribution to the study of ancient Egypt will be the support and involvement of the Ministry of Antiquities, as well as that of individual archaeologists and missions, conservators, and other scientists and their institutions. Collaboration among experienced dendrochronologists, Egyptologists, and Egyptian scientists, archaeologists, and students would introduce tree-ring methodologies not only to the field of Egyptology but also to the community of Egyptian researchers. Indeed, Egypt faces other pressing concerns (e.g. Nile river flow and water management today) that could greatly benefit from the introduction of tree-ring research.

Although not a panacea for all of the chronological and environmental questions regarding Egypt and the ancient world around it, dendrochronology can and must serve as a critical bridge toward the development of a greater understanding. This development will happen neither quickly nor easily; an endeavor of this scope will be long, arduous, and beset by challenges (including scientific and logistical). Furthermore, however great its value, we must employ dendrochronology in concert with those other tools available, including the very historical records (e.g. king lists), archaeological interpretations, ${ }^{14} \mathrm{C}$ dating, Sothic cycles, and synchronisms with other cultures on which the problematic chronologies currently in use are built. Only by combining dendrochronology with other such modes of investigation can we realize its true potential for Egypt and neighboring regions and thereby provide other researchers with precise dates on which to ground their historical discussions.

\section{REFERENCES}

Adams, B., 2001. Locality 6 in 2000: Amazing revelations. Nekhen News 13:4-7

Akkemik, Ü., and B. Yaman, 2012. Wood Anatomy of Eastern Mediterranean Species. Kessel, Remagen-Oberwinter, Germany.

Allen, J. G., 1924. Letter to A. E. Douglass, University of Arizona, Tucson, Arizona, USA, dated 7 January 1924. Unpublished letter. On file at the Laboratory of Tree-Ring Research, University of Arizona, Tucson.

Andersen, G. L., and K. Krzywinski, 2007. Mortality, recruitment and change of desert tree populations in a hyper-arid environment. PLOS ONE 2(2):e208, doi: 10.1371/journal.pone.0000208.

Andersen, G. L., K. Krzywinski, M. Talib, A. E. M. Saadallah, J. J. Hobbs, and R. H. Pierce, 2014. Traditional nomadic tending of trees in the Red Sea Hills. Journal of Arid Environments 106:36-44.

Baillie, M. G. L., 1982. Tree-Ring Dating and Archaeology. University of Chicago Press, Chicago.

Bannister, B., 1963. Dendrochronology. In Science in Archaeology: A Comprehensive Survey of Progress and Research, edited by D. R. Brothwell and E. S. Higgs; pp. 162-176. Basic, New York.

Bannister, B., 1970. Dendrochronology in the Near East: Current research and future potentialities. In Proceedings of the Seventh International Congress of Anthropological and Ethnological Sciences, volume 5; pp. 336-340. Reprinted: Tree-Ring Bulletin 1997 Special Issue.

Bannister, B., 1985. Letter to D. Watters, Carnegie Museum of Natural History, Pittsburgh, Pennsylvania, USA, dated 3 October 1985. Unpublished letter. On file at the Laboratory of Tree-Ring Research, University of Arizona, Tucson.

Bannister, B., and W. J. Robinson, 1975. Tree-ring dating in archaeology. World Archaeology 7(2):210-225.

Bannister, B., and W. J. Robinson, 1986. Archaeology and dendrochronology. In Emil W. Haury's Prehistory of the American Southwest, edited by J. J. Reid and D. E. Doyel; pp. 49-54. University of Arizona Press, Tucson.

Bardinet, T., 2008. Relations économiques et pressions militaires en méditerranée orientale et en Libye au temps des pharaons. Etudes et mémoires d'égyptologie 7. Cybele, Paris.

Bell, B., 1971. The Dark Ages in ancient history I: The first Dark Age in Egypt. American Journal of Archaeology 75(1):1-26.

Bell, B., 1975. Climate and the history of Egypt: The Middle Kingdom. American Journal of Archaeology 79(3):223-269.

Bernhardt, C. E., B. P. Horton, and J.-D. Stanley, 2012. Nile Delta vegetation response to Holocene climate variability. Geology 40(7):615-618.

Breasted, J. H., 1933. Letter to A. E. Douglass, University of Arizona, Tucson, Arizona, USA, dated 1 November 1933. Unpublished letter. On file at the Laboratory of Tree-Ring Research, University of Arizona, Tucson.

Bronk Ramsey, C., M. Dee, J. Rowland, T. Higham, S. Harris, F. Brock, A. Quiles, E. Wild, E. Marcus, and A. Shortland. 2010. Radiocarbon-based chronology for dynastic Egypt. Science 328(5985):1554-1557.

Bruins, H. J., 2010. Dating pharaonic Egypt. Science 328(5985):1489-1490.

Bull, L., 1942. Letter to A. E. Douglass, University of Arizona, Tucson, Arizona, USA, dated 30 June 1942. Unpublished letter. On file at the Laboratory of Tree-Ring Research, University of Arizona, Tucson.

Butzer, K., 2012. Collapse, environment, and society. Proceedings of the National Academy of Sciences of the USA 109(10):3032-3039.

Cichocki, O., 2000. Methods and aims in dendrochronology. Dating wooden objects from the eastern Mediterranean in the second millennium B.C. (Absolute Chronology IV). In The Synchronization of Civilizations in the Eastern Mediterranean in the Second Millennium B.C. Proceedings of an International Symposium at Schloss Haindorf, 15th-17th of November 1996 and at the Austrian Academy, Vienna, 11th-12th of May 1998, edited by M. Bietak; pp. 6267. Verlag der Österreichischen Akademie der Wissenschaften, Vienna.

Cichocki, O., 2003. Dendrochronological investigations on cedar objects of ancient Egypt. In The Synchronization of Civilizations in the Eastern Mediterranean in the Second Millennium B.C. II. Proceedings of the SCIEM 2000-EuroConference, Haindorf, 2nd of May-7th of May 2001, CChEM 4, edited by M. Bietak; pp. 43-49. Verlag der Österreichischen Akademie der Wissenschaften, Vienna.

Cichocki, O., 2006. Libanesische Zedern als Datierungswerkzeug in der ägyptischen Archäologie. In Timelines: Studies in Honour of Manfred Bietak, ed- 
ited by E. Czerny, I. Hein, H. Hunger, D. Melman, and A. Schwab; pp. 293299. Volume 2. Orientalia Lovaniensia Analecta 149. Peeters, Louvain.

Cichocki, O., M. Bichler, G. Firneis, W. Kutschera, W. Müller, and P. Stadler, 2004. The synchronization of civilizations in the eastern Mediterranean in the second millennium BC: Natural science dating attempts. In Tools for Constructing Chronologies: Crossing Disciplinary Boundaries, edited by C. E. Buck and A. R. Millard; pp. 83-108. Springer, London.

Creasman, P. P., 2010a. A further investigation of the Cairo Dahshur boats. Journal of Egyptian Archaeology 96:101-123.

Creasman, P. P., 2010b. Extracting Cultural Information from Ship Timber. Doctoral dissertation, Texas A\&M University, College Station.

Creasman, P. P., 2011. Basic principles and methods of dendrochronological specimen curation. Tree-Ring Research 67(2):103-115.

Creasman, P. P., 2013a. Egyptian chronology. In Archaeological Research in the Valley of the Kings and Ancient Thebes: Papers Presented in Honor of Richard H. Wilkinson, edited by P. P. Creasman; pp. xvii-xix. Wilkinson Egyptology Series I: University of Arizona Egyptian Expedition, Tucson.

Creasman, P. P., 2013b. Ship timber and the reuse of wood in ancient Egypt. Journal of Egyptian History 6(2):152-176.

Creasman, P. P., 2014. Reflections of a timber economy: The interpretation of Middle Kingdom ship and boat timbers. Göttinger Miszellen 240:19-36.

Creasman, P. P., in press. The potential of dendrochronology in Egypt: Understanding ancient human/environment interactions. In Bioarchaeology of Ancient Egypt, edited by S. Ikram, J. Kaiser, and R. Walker. Sidestone Press, Leiden.

Creasman, P. P., B. Bannister, R. H. Towner, J. S. Dean, and S. W. Leavitt, 2012. Reflections on the foundation, persistence, and growth of the Laboratory of Tree-Ring Research, circa 1930-1960. Tree-Ring Research 68(2):81-89.

Creasman, P. P., W. R. Johnson, J. B. McClain, and R. H. Wilkinson. 2014. Foundation or completion? The status of pharaoh-Queen Tausret's temple of millions of years. Near Eastern Archaeology 77(4): in press.

Dean, J., 1978. Tree-ring dating in archaeology. In University of Utah Anthropological Papers: Misc. Paper 24, edited by J. Jennings; pp. 129-163. University of Utah Press, Salt Lake City.

Dean, J. S., 1996. Dendrochronology and the study of human behavior. In Tree Rings, Environment and Humanity: Proceedings of the International Conference, Tucson, Arizona 17-21 May 1994, edited by J. S. Dean, D. Meko, and T. W. Swetnam; pp. 461-469. Radiocarbon, Tucson.

Dee, M. W., F. Brock, S. A. Harris, C. Bronk Ramsey, A. J. Shortland, T. F. G. Higham, and J. M. Rowland, 2010. Investigating the likelihood of a reservoir offset in the radiocarbon record for ancient Egypt. Journal of Archaeological Science 37(4):687-693.

Dee, M. W., J. M. Rowland, T. F. G. Higham, A. J. Shortland, F. Brock, S. A. Harris, and C. Bronk Ramsey, 2012. Synchronising radiocarbon dating and the Egyptian historical chronology by improved sample selection. Antiquity 86(333):868-883.

Deglin, F., 2012. Wood exploitation in ancient Egypt: Where, who, and how? In Current Research in Egyptology 2011. Proceedings of the Twelfth Annual Symposium, edited by H. Abd El Gawad, N. Andrews, M. Correas-Amador, V. Tamorri, and J. Taylor; pp. 85-96. Oxbow, Oxford.

Dixon, D. M., 1974. Timber in ancient Egypt. Commonwealth Forestry Review 53(3):205-209.

Dorman, P. F., 2009. The long coregency revisited: Architectural and iconographic conundra in the tomb of Kheruef. In Causing His Name to Live: Studies in Egyptian Epigraphy and History in Memory of William J. Murnane, edited by P. J. Brand and L. Cooper; pp. 65-82. Brill, Leiden.

Douglass, A. E., 1929. The secret of the Southwest solved by talkative tree rings. National Geographic Magazine 56(6):736-770.

Douglass, A. E., 1936. Letter to S. Stallings, dated 29 February 1936. Unpublished letter. On file at the Laboratory of Tree-Ring Research, University of Arizona, Tucson.

Eshete, G., and G. Ståhl, 1999. Tree rings as indicators of growth periodicity of acacias in the Rift Valley of Ethiopia. Forest Ecology and Management 116(1-3):107-117.

Fahn, A., E. Werker, and P. Baas, 1986. Wood Anatomy and Identification of Trees and Shrubs from Israel and Adjacent Regions. The Israel Academy of Sciences and Humanities, Jerusalem.
Ferguson, C. W., 1969. A 7104-year annual tree-ring chronology for bristlecone pine, Pinus aristata, from the White Mountains, California. Tree-Ring Bulletin 29(3-4):3-29.

Gale, R., P. Gasson, N. Hepper, and G. Killen, 2000. Wood. In Ancient Egyptian Materials and Technology, edited by P. T. Nicholson and I. Shaw; pp. 334371. Cambridge University Press, Cambridge.

Ghilardi, M., and M. Boraik, 2011. Reconstructing the Holocene depositional environments in the western part of ancient Karnak temples complex (Egypt): A geoarchaeological approach. Journal of Archaeological Science 38(12):32043216.

Giles, F. J., 2001. The Amarna Age: Egypt. Australian Centre for Egyptology: Studies 6. Aris and Philips, Warminster.

Gourlay, I. D., 1995a. The definition of seasonal growth zones in some African Acacia species-A review. International Association of Wood Anatomists Journal 16(4):353-359.

Gourlay, I. D., 1995b. Growth ring characteristics of some African Acacia species. Journal of Tropical Ecology 11(1):121-140.

Grabner, M., D. Salaberger, and T. Okochi, 2009. The need of high resolution $\mu$-X-ray in dendrochronology and in wood identification. In ISPA 2009: Proceedings of the 6th International Symposium on Image and Signal Processing and Analysis: Salzburg, Austria, September 16-18, 2009, edited by P. Zinterhof, A. Uhl, S. Loncaric, and A. Carini; pp. 349-352. University of Salzburg, Salzburg, and Faculty of Electrical Engineering and Computing, University of Zagreb, Zagreb.

Graham, A., D. K. D. Strutt, M. Hunter, S. Jones, A. Masson, M. Millet, and B. Pennington, 2012. Reconstructing landscapes and waterscapes in Thebes, Egypt. eTopoi Journal for Ancient Studies Special Volume 3:135-142.

Gray, S. T., J. J. Lukas, and C. A. Woodhouse, 2011. Millennial-length records of streamflow from three major upper Colorado River tributaries. Journal of the American Water Resources Association 47(4):702-712.

Griggs, C., A. DeGaetano, P. Kuniholm, and M. Newton, 2007. A regional high-frequency reconstruction of May-June precipitation in the north Aegean from oak tree rings, A.D. 1089-1989. International Journal of Climatology 27(8):1075-1089.

Hassan, F., 2007. Droughts, famine, and the collapse of the Old Kingdom: Re-reading Ipuwer. In The Archaeology of Art and Ancient Egypt: Essays in Honor of David B. O'Connor, edited by Z. Hawass and J. Richards; pp. 357-377. Supreme Council of Antiquities, Cairo.

Haury, E. W., 1935. Tree rings: The archaeologist's time-piece. American Antiquity 1(2):98-108.

Höflmayer, F., 2012. The date of the Minoan Santorini eruption: Quantifying the "offset." Radiocarbon 54(3-4):435-448.

Hornung, E., R. Krauss, and D. A. Warburton, 2006. Ancient Egyptian Chronology. Brill, Leiden.

Janssen, J. J., 1961. Two Ancient Egyptian Ship’s Logs: Papyrus Leiden I 350 verso and Papyrus Turin 2008+2016. Brill, Leiden.

Khan, D., 2006. Divided kingdom, coregency, or sole rule in the kingdom(s) of Egypt-and-Kush? In Proceedings of SCIEM 2005, edited by M. Bietak; pp. 235-252. Ägypten und Levante 16. Verlag der Österreichischen Akademie der Wissenschaften, Vienna.

Kingsley, P., 2014. Archaeologists find remains of previously unknown pharaoh in Egypt. The Guardian, 22 January 2014. http://www.theguardian.com/science/2014/jan/22/archaeologists-remains-unknown-pharaoh-egypt (Accessed 31 January 2014).

Kitchen, K. A., 2006. The strengths and weaknesses of Egyptian chronology-A reconsideration. Egypt and the Levant 16:293-308.

Kitchen, K. A., 2013. Establishing chronology in pharaonic Egypt and the ancient Near East: Interlocking textual sources relating to c. 1600-664 BC. In Radiocarbon and the Chronologies of Ancient Egypt, edited by A. J Shortland and C. Bronk Ramsey; pp. 1-18. Oxbow Books, Oxford.

Kromer, K., 1991. Nezlet Batran-eine Mastaba aus dem Alten Reich bei Giseh (Ägypten). Verlag der Österreichischen Akademie der Wissenschaften, Vienna.

Kuniholm, P. I., 1992. Aegean Dendrochronology Project, Annual Report 1991. Cornell University, Ithaca.

Kuniholm, P. I., 2000. Dendrochronology (tree-ring dating) of panel paintings. In The Science of Paintings, edited by W. S. Taft and J. W. Mayer; pp. 207-217. 
Springer, New York.

Kuniholm, P. I., 2001a. Aegean Dendrochronology Project 1999-2000. Arkeometrı Sonuçları Toplantısı 16(1):79-84.

Kunholm, P. I., 2001b. Dendrochronology and other applications of tree-ring studies in archaeology. In Handbook of Archaeological Sciences, edited by D. R. Brothwell, and A. M. Pollard; pp. 35-46. John Wiley \& Sons, New York.

Kuniholm, P. I., 2002. Archaeological dendrochronology. Dendrochronologia 20(1/2):63-68.

Lansing, A., 1938. Letter to A. E. Douglass, University of Arizona, Tucson, Arizona, USA, dated 15 June 1938. Unpublished letter. On file at the Laboratory of Tree-Ring Research, University of Arizona, Tucson.

Lichtheim, M., 1976. Ancient Egyptian Literature III. The New Kingdom. University of California Press, Berkeley.

Liphschitz, N., 2007. Timber in Ancient Israel: Dendroarchaeology and Dendrochronology. Institute of Archaeology, Tel Aviv University, Tel Aviv.

Manning, S. W., M. W. Dee, E. M. Wild, C. Bronk Ramsey, K. Bandy, P. P. Creasman, C. B. Griggs, C. L. Pearson, A. J. Shortland, and P. Steier, 2014. High-precision dendro- ${ }^{14} \mathrm{C}$ dating of two cedar wood sequences from First Intermediate Period and Middle Kingdom Egypt and a small regional climate-related ${ }^{14} \mathrm{C}$ divergence. Journal of Archaeological Science 46:401-416.

Manning, S. W., and B. Kromer, 2012. Considerations of the scale of radiocarbon offsets in the east Mediterranean, and considering a case for the latest (most recent) likely date for the Santorini eruption. Radiocarbon 54(3-4):328-340.

Mark, S., 2009. The construction of the Khufu I vessel (c. 2566 BC): A re-evaluation. International Journal of Nautical Archaeology 38(1):133-152.

Moeller, N., 2005. The First Intermediate Period: A time of famine and climate change? Egypt and the Levant 15:153-167.

Nash, S. E., 1999. Time, Trees, and Prehistory. University of Utah Press, Salt Lake City.

Nicolini, G., V. Tarchiani, M. Saurer, and P. Cherubini, 2010. Wood-growth zones in Acacia seyal Delile in the Keita Valley, Niger: Is there any climatic signal? Journal of Arid Environments 74(3):355-359.

Quiles, A., E. Auborg, B. Berthier, E. Delque-Količ, G. Pierrat-Bonnefois, M. W. Dee, G. Andreu-Lanoë, C. Bronk Ramsey, and C. Moreau, 2013. Bayesian modelling of an absolute chronology for Egypt's 18th Dynasty by astrophysical and radiocarbon methods. Journal of Archaeological Science 40(1):423-432.

Redford, D. B., editor, 2001. The Oxford Encyclopedia of Ancient Egypt. 3 volumes. Oxford University Press, Oxford.

Renfrew, C., 1996. Kings, tree rings and the Old World. Nature 381(6585):733734.

Robinson, W. J., 1967. Tree-Ring Materials as a Basis for Cultural Interpretations. Doctoral dissertation, University of Arizona, Tucson.

Robinson, W. J., 1976. Tree-ring dating and archaeology in the American Southwest. Tree-Ring Bulletin 36:9-20.

Ryholt, K. S. B., 1997. The Political Situation in Egypt during the Second Intermediate Period c. 1800-1550 B.C. Museum Tusculanum Press, Copenhagen.

Schneider, T., 2010. Contributions to the chronology of the New Kingdom and the Third Intermediate Period. Egypt and the Levant 20:373-403.
Schneider, T., 2012. Le casse-tête de la chronologie égyptienne. Pour la science 413:28-33.

Shaw, I., 2000a. Introduction: chronologies and cultural change in Egypt. In The Oxford History of Ancient Egypt, edited by I. Shaw; pp. 1-17. Oxford University Press, Oxford.

Shaw, I., editor, 2000b. The Oxford History of Ancient Egypt. Oxford University Press, Oxford

Shortland, A. J., and C. Bronk Ramsey, 2013. Radiocarbon and the Chronologies of Ancient Egypt. Oxbow Books, Oxford.

Simpson, W. K., 1965. Papyrus Reisner II. Accounts of the Dockyard Workshop at This in the Reign of Sesostris I. Museum of Fine Arts, Boston.

Spence, K., 2000. Ancient Egyptian chronology and the astronomical orientation of the pyramids. Nature 408(6810):320-324.

Suess, H. E., 1970. Bristlecone-pine calibration of the radiocarbon time-scale $5200 \mathrm{BC}$ to the present. In Radiocarbon Variations and Absolute Chronology. Proceedings of the 13th Nobel Symposium, edited by I. U. Olsson; pp. 303312. Almqvist \& Wichsell, Stockholm.

Tolera, M., U. G. W. Sass, A. Ashete, F. Bongers, and F. J. Sterck, 2013. Frankincense tree recruitment failed over the past half century. Forest Ecology and Management 304:65-72.

Touchan, R., and M. K. Hughes, 2009. Dendroclimatology in the Near East and eastern Mediterranean region. In Tree-Rings, Kings, and Old World Archaeology and Environment. Papers Presented in Honor of Peter Ian Kuniholm, edited by S. W. Manning and M. J. Bruce; pp. 65-70. Oxbow Books, Oxford.

Touchan, R., K. J. Anchukaitis, D. M. Meko, M. Sabir, S. Attalah, and A. Aloui, 2011. Spatiotemporal drought variability in northwestern Africa over the last nine centuries. Climate Dynamics 37(1-2):237-252.

Trouet, V., M. Mukelabai, A. Verheyden, and H. Beeckman, 2012. Cambial growth season of brevi-deciduous Brachystegia spiciformis trees from south central Africa restricted to less than four months. PLoS One 7(10):e47364, doi: 10.1371/journal.pone.0047364.

van Dijk, J., 2008. New evidence on the length of the reign of Horemheb. Journal of the American Research Center in Egypt 44:193-200.

Ward, C., 2000. Sacred and Secular: Ancient Egyptian Ships and Boats. Archaeological Institute of America Monographs 5. University Museum, Philadelphia.

Wiener, M. H., 2006. Egypt and time. Egypt and the Levant 16:325-339.

Wilkinson, R. H., editor, 2012. Tausret: Forgotten Queen and Pharaoh of Egypt. Oxford University Press, Oxford.

Wils, T. H. G., I. Robertson, Z. Eshetu, M. Koprowski, U. G. W. Sass-Klaassen, R. Touchan, and N. J. Loader, 2010. Towards a reconstruction of Blue Nile baseflow from Ethiopian tree rings. The Holocene 20(6):837-849.

Wils, T. H. G., U. G. W. Sass-Klaassen, Z. Eshetu, A. Bräuning, A. Gebrekirstos, C. Couralet, I. Robertson, R. Touchan, M. Koprowski, D. Conway, K. R. Briffa, and H. Beeckman, 2011. Dendrochronology in the dry tropics: The Ethiopian case. Trees 25(3):345-354.

Woodhouse, C. A., and J. T. Overpeck, 1998. 2000 years of drought variability in the central United States. Bulletin of the American Meteorological Society 79(12):2693-2714. 